\title{
Numerical Modeling of Encased Stone Columns Supporting Embankments on Sabkha Soil
}

\author{
Imad Eddine Debbabi ${ }^{a^{*}}$, Remadna Mohamed Saddek ${ }^{\mathrm{a}}$, Ahmad Safuan A. Rashid ${ }^{\mathrm{b}}$, \\ Abubakar Sadiq Muhammed ${ }^{\mathrm{c}}$ \\ ${ }^{a}$ Department of Civil Engineering and Hydraulic, NMISSI Laboratory, Biskra University, BP 145, Biskra 07000, Algeria.
}

${ }^{b}$ Centre of Tropical Geoengineering (GEOTROPIK), School of Civil Engineering, Universiti Teknologi Malaysia, Johor Bahru 81310, Malaysia.

${ }^{c}$ Department of Civil and water Resources Engineering, University of Maiduguri, Borno Nigeria.

Received 13 May 2020; Accepted 19 July 2020

\begin{abstract}
The present research work is concerned with the construction of road embankments on a specific soil called Sabkha in Algeria. This soil is not only soft and very humid during the flooding seasons but also has frequent small areas of very soft soil which we here call Locally Weak Zones (LWZ). LWZ is characterized by low strength and high compressibility. The paper presents the results of two-dimensional axisymmetric numerical analyze that were carried out using PLAXIS 2D 2017, for the modeling of an embankment supported by stone columns on Sabkha soil. The study focuses on the evaluation of the maximum bulging of the stone column and on the settlement of the embankment. It has been demonstrated that Ordinary Stone Columns (OSC) were ineffective due to excessive bulging $(221.16 \mathrm{~mm})$ caused by the lack of lateral pressure. On the other hand, the Encased Stone Columns (ESC) showed good behavior, namely a much reduced bulging $(42.09 \mathrm{~mm})$ and a reasonable settlement $(0.962 \mathrm{~m} \mathrm{vs.} 1.560 \mathrm{~m}$ for an OSC) so that it is possible to build safe very high embankments. The numerical analysis also shows that the length of the encasement should just be greater than the depth of the LWZ. Besides, an extensive parametric study was conducted to investigate the effects of the variations of embankment height, stiffness of geosynthetic, the depth of the locally weak zone, area replacement ratio (ARR), and the stone column friction angle, on the performance of the (ESC) - embankment composite in (LWZ). Some important guidelines for selecting the ideal encased stone column (ESC) to support embankments on over locally weak zone were established through this numerical study.

Keywords: Encased Stone Columns; Geosynthetic; Finite Element Modelling; Locally Weak Zone; Sabkha Soil.
\end{abstract}

\section{Introduction}

Nowadays, structures such as dams, road embankments and storage tanks, frequently have many problems with irregular, excessive settlements or overall stability due to geological situation and weak soil. Stone columns (likewise known as granular piles) are increasingly used as soft soil reinforcement to support a variety of structures [1], in other words, these are soft soil improvement techniques which are commonly and successfully used to reduce settlement, reduce the liquefaction potential, and to speed up the consolidation of soft soils [2-4]. When the stone columns (OSCs) are installed in extremely soft soils (cu $<15 \mathrm{kPa}$ ) such as peat soils, and marine clays, etc., the lateral confinement presented by the surrounding soil may not be sufficient to form the stone column. This may lead to the excessive bulging of stone columns, especially in the upper portion of the columns, which can significantly reduce their capacity

${ }^{*}$ Corresponding author: imadeddine.debbabi@univ-biskra.dz

http://dx.doi.org/10.28991/cej-2020-03091569

(C) 2020 by the authors. Licensee C.E.J, Tehran, Iran. This article is an open access article distributed under the terms and conditions of the Creative Commons Attribution (CC-BY) license (http://creativecommons.org/licenses/by/4.0/). 
due to low bearing capacity and high compressibility [5-7]. The shear failure mechanism was explained by Madhav et al [8]. The punching failure mechanism was investigated by Brauns [9], and sliding by Aboshi et al. [10].

Since the performance of ordinary stone columns is highly dependent on the lateral confinement provided by surrounding soil, when it comes to very soft soils $(\mathrm{Su}<15 \mathrm{kPa})$ the application of this solution may not be feasible, different techniques have been proposed to reinforce the performance of ordinary stone columns (OSCs). Aboshi et al. [10] reinforced the top portion of the column with a steel skirt. The deep mixing method was used by Rashid et al. [11], and horizontal layers of geogrid in the top portion of the column were adopted by Sharma [12]. In addition, Murtaza and Samadhiya [13] reinforced the stone columns with horizontal geogrid strips. Rao and Bhandari [14] used concrete plugs to prevent lateral bulging of the stone columns. As Juran and Riccobono [15] suggested mixing the granular material that is placed at the top of each column with cement.

Another method that can be used to provide the required lateral confining pressure to increase the bearing capacity of granular columns is to encase the column with a suitable geosynthetic. The columns may be encased with geosynthetics which are the main materials used to increase the strength and stability of geotechnical structures. The idea of encased stone columns was first proposed by Van Impe [16]. This technique has been successfully used in different projects $[17,18]$. The main advantage of geosynthetic encased stone columns (ESCs) over ordinary stone columns (OSCs) is the higher stiffness resulting from the hoop force in the geosynthetic, which ascent the load capacity. In addition, the encasement prevents the lateral intermix of the granular material with the surrounding soft soil and thus does not influence the drainage capacity of the stone columns.

Encased stone columns have been studied in different ways. Malarvizhi and Ilamparuthi [19] studied the behavior of floating encased stone columns and end-bearing columns through small-scale model tests. Ayadat and Hanna [20] presented an experimental study of the performance of (ESCs). Similarly, Murugesan and Rajagopal [21] carried laboratory model tests to investigate the shear load capacity of stone columns with and without geosynthetic encasement. However, not many analytical solutions for encased stone columns have been presented in the literature. Raithel and Kempfert [22] developed numerical and analytical calculation models for the design of a geotextile-coated sand-column foundation system. The deformation characteristics of stone columns in terms of axial compression accompanied by lateral expansion are taken into account in the proposed analytical method. Based on the unit-cell concept, analytical solutions to the study the total settlement at the tops of geosynthetic-encased stone columns are suggested by Castro and Sagaseta [23], and Pulko et al. [24]. Zhang et al. [25] proposed a theoretical elastic solution of stresses and displacements of a composite foundation with GECs. And other theoretical studies were carried out by Zhou and Gangqiang [26] and Duan et al. [27]. Theoretical analysis is lagging behind. Assuming that a composite foundation with GECs satisfies the equal strain condition and rests on a rigid layer, and that the volume of the column remains constant. Many successful numerical studies of encased granular columns are also available in the literature [28-30]. In order to evaluate the effect of geosynthetic encasement on the behavior of stone columns, axisymmetric analyses and unit cell concept have been adopted [31,32] and sometimes complemented by full-scale embankment loading [32].

This study is concerned with the construction of road embankments on a specific soft soil called Sabkha. This soil is not only soft and very humid during the flooding seasons but also has frequent small areas of very soft soil which is here call locally weak zones $(L W Z)$. LWZ is characterized by low strength and high compressibility (the coefficient of compressibility averages a value of 6).

It must be said that, numerous researches carried out during the last two decades, have examined and characterized the behavior of sabkha soils. Different approaches have been proposed to stabilize sabkha soils, in particular the use of chemical and mechanical processes (Akili et al. [33], Abduljauwad and Al-Amoudi [34]). However, no research till now has taken into account the reinforcement of the soil of Sabkha by encased stone columns. In this context, this research work is presented as a contribution in the form of a numerical modeling that studies the behavior of road embankments built on sabkha soil reinforced by encased stone columns and using a geotechnical data for (LWZ) from a real site in Algeria.

This paper presents the results of two-dimensional (2-D) unit cell finite element analyses that were carried out to investigate the behavior of the embankments built on soft grounds presenting locally weak zones (Sabkha soil). The study shows, among other results, the absolute necessity of wrapping stone columns with geosynthetic for this type of soil. Otherwise, the backing of the embankment is not suitable without encased stone columns.

This study is presented in the following sequences. First, the adopted model (FEM) is verified by analytical methods $[22,24,35]$, and then the results are compared with an already published numerical study. All the relating to the geometry and geotechnical characteristics, are of course, identical to the studies of comparison. Subsequently, the discussion and validation of our numerical model, the improvement of the embankment response through the use of encasement was investigated. Then an intense parametric study is carried out to determine the sensitivity of the targeted results (i.e. lateral deformation of the column and vertical settlement) with regard to the variation of the 
principal parameters, namely, the height of the embankment, the rigidity of the geosynthetic, the length of the envelope, the area replacement ratio (ARR), the thickness of the Sabkha layer, and the angle of friction of the granular material constituting the stone column. All the results are discussed as the study is progressing and finally, a conclusion was drawn at the end of the study. Figure 1 shows a flowchart of the research methodology.

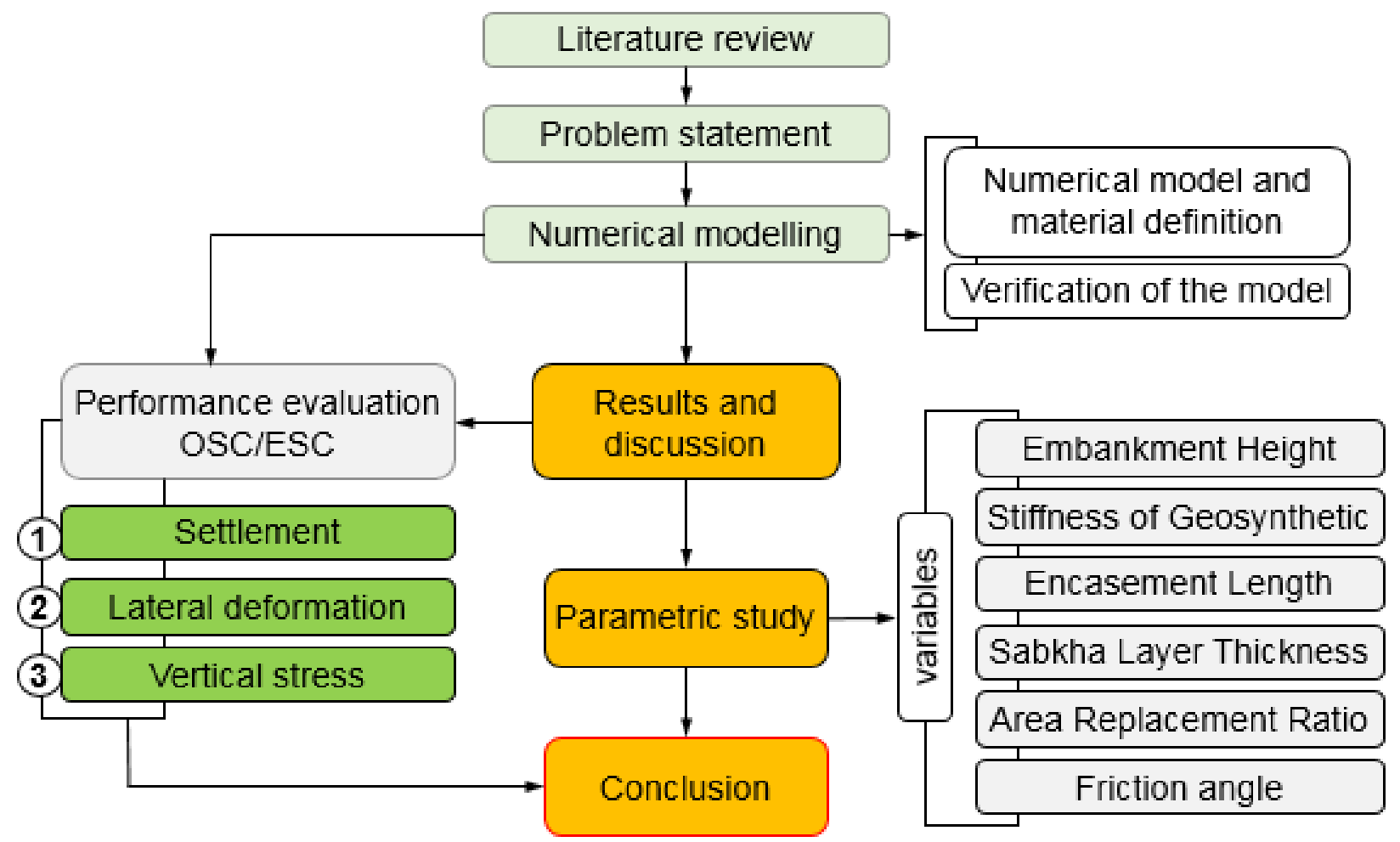

Figure 1. Research methodology flowchart

\section{Problem Definition of Locally Weak Zones (LWZ)}

Field explorations in Chott el Hodna in Algeria have shown that locally weak zones are mostly circular in shape [36] see Figure 2a. The nature of sabkha soils both chemically and physically causes some problems during construction with stone columns. These problems were identified by several researchers [33, 34]. The most common problems are the compressibility of sabkha soil which varies from one point to another and can lead to large differential settlement. Sabkha deposit can withstand high pressures in dry conditions but when wet it exhibits high deformation and low shear strength and hence poses great challenges to the engineers. Khan and Hasnain [37], as massive reported severe damage to a large number of buildings and roads constructed on sabkha soils in Libya, USA, China [38] see Figure 2b and Saudi Arabia. In this study, interesting solutions are suggested to solve the problems of Sabkha soil $(L W Z)$, especially during the rainy seasons.
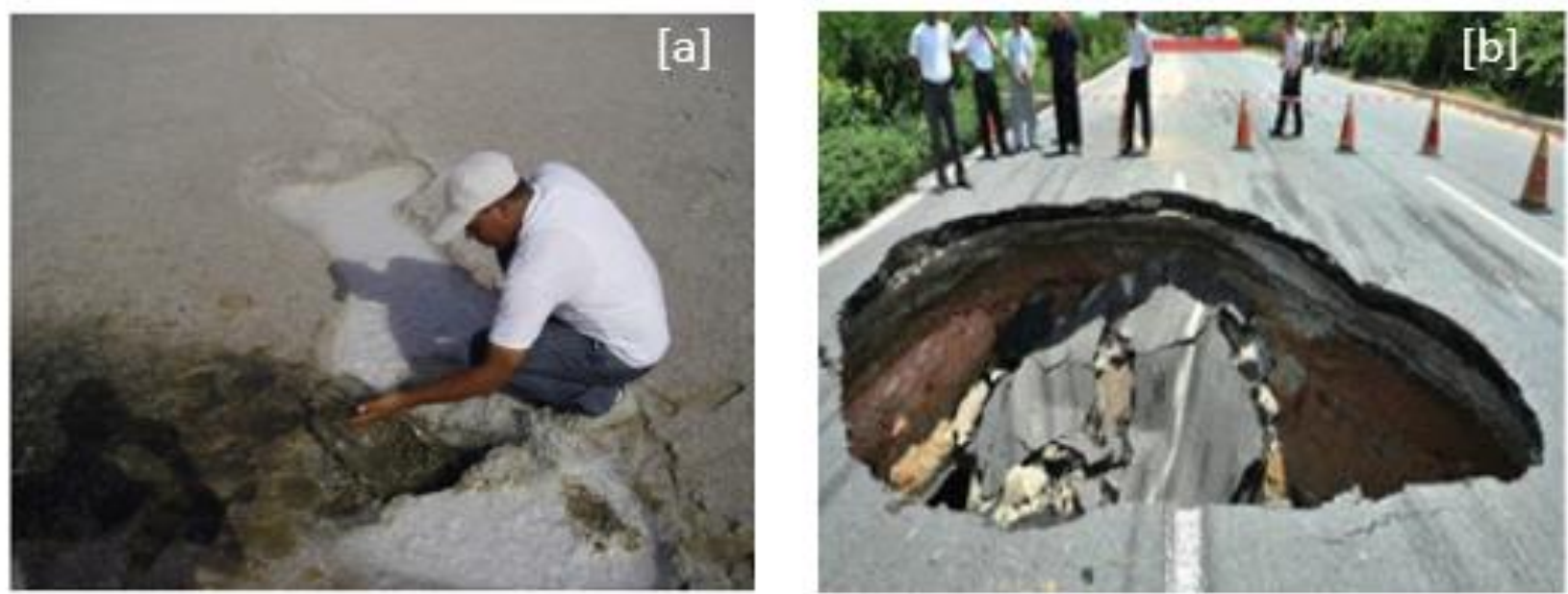

Figure 2. Example of the locally weak zone 


\section{Numerical Modeling}

\subsection{Presentation of the Finite Element Model and Material Parameters}

In order to simulate the unit cell, an axisymmetric model was undertaken using the finite element code PLAXIS 2D V2017 program available commercially to analyse deformation and stability for a variety of geotechnical problems. In this numerical analysis, a very fine mesh was used because stresses and displacements are very high in this problem. The problem of using a stone column to support a large embankment over locally weak zone (Sabkha soil) was studied.

Appropriate choices of material properties are necessary to have an accurate simulation of the reinforcement system in numerical modelling. The properties of the embankment, soft clay, stone columns can be found in the literature Alkhorshid et al. [39]. The columns were installed in a square grid with spacing, $\mathrm{s}=2.5 \mathrm{~m}$ supporting an embankment of $10 \mathrm{~m}$ high (Hemb). The thickness of the clay soil and the length of the stone column are assumed to be $10 \mathrm{~m}$ underlain by a rigid, hard stratum. the radius of the column within the unit cell $r_{c}$, was equal to 0.4 m, radius of the influence area of the column $r_{e}=1.4 \mathrm{~m}$, area replacement ratio ( $\mathrm{Arr}=\mathrm{r}_{\mathrm{c}}^{2} / \mathrm{r}_{\mathrm{e}}^{2}$ ) equal to $8.16 \%$, and geosynthetic tensile stiffness (J) equal to $2000 \mathrm{kN} / \mathrm{m}$. The dimensions and properties of the locally weak zone (Sabkha soil) were chosen to match values stated by Benmebarek et al. [36] as B $=0.6 \mathrm{~m}$ and DEP $=3 \mathrm{~m}$ respectively width and depth of the LWZ as shown schematically in Figure 3c. The groundwater level is assumed at the ground surface. The vertical or horizontal displacements were restrained at the bottom boundaries of the unit cell, but vertical displacements were allowed at the lateral borders. Concerning the constitutive models, the soft clay was simulated using the Hardening Soil (HS) model, which is stress-dependent. An elastoplastic Mohr-Coulomb model was adopted for both the granular column and the embankment material, and locally weak zone behavior was represented by the soft soil model (SSM). The behavior of the geosynthetic was simulated using line elements with two translational degrees of freedom at each node. Geosynthetic can sustain only tensile forces and be modelled as a linear elastic material with tensile stiffness J. The geosynthetic encasement used in this study was geotextile type branded as Ringtrac. Ringtrac is a registered trademark of HUESKER Synthetic GmbH. Table 1 shows the parameters used in the FEM.

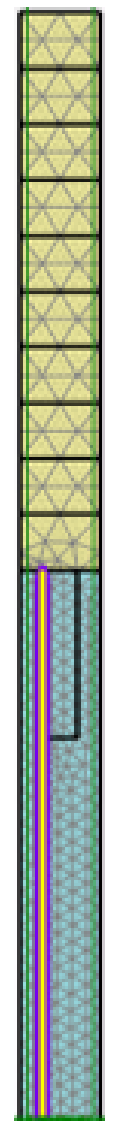

(a)

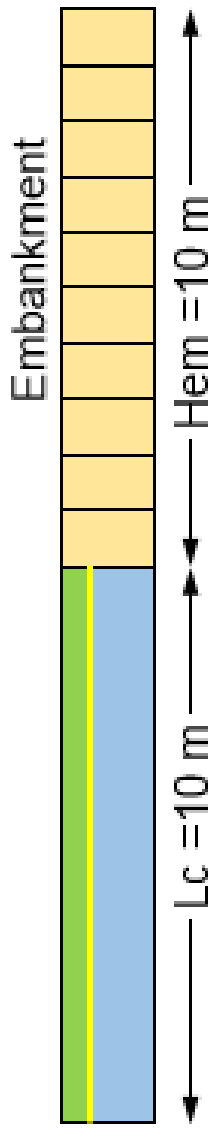

(b)

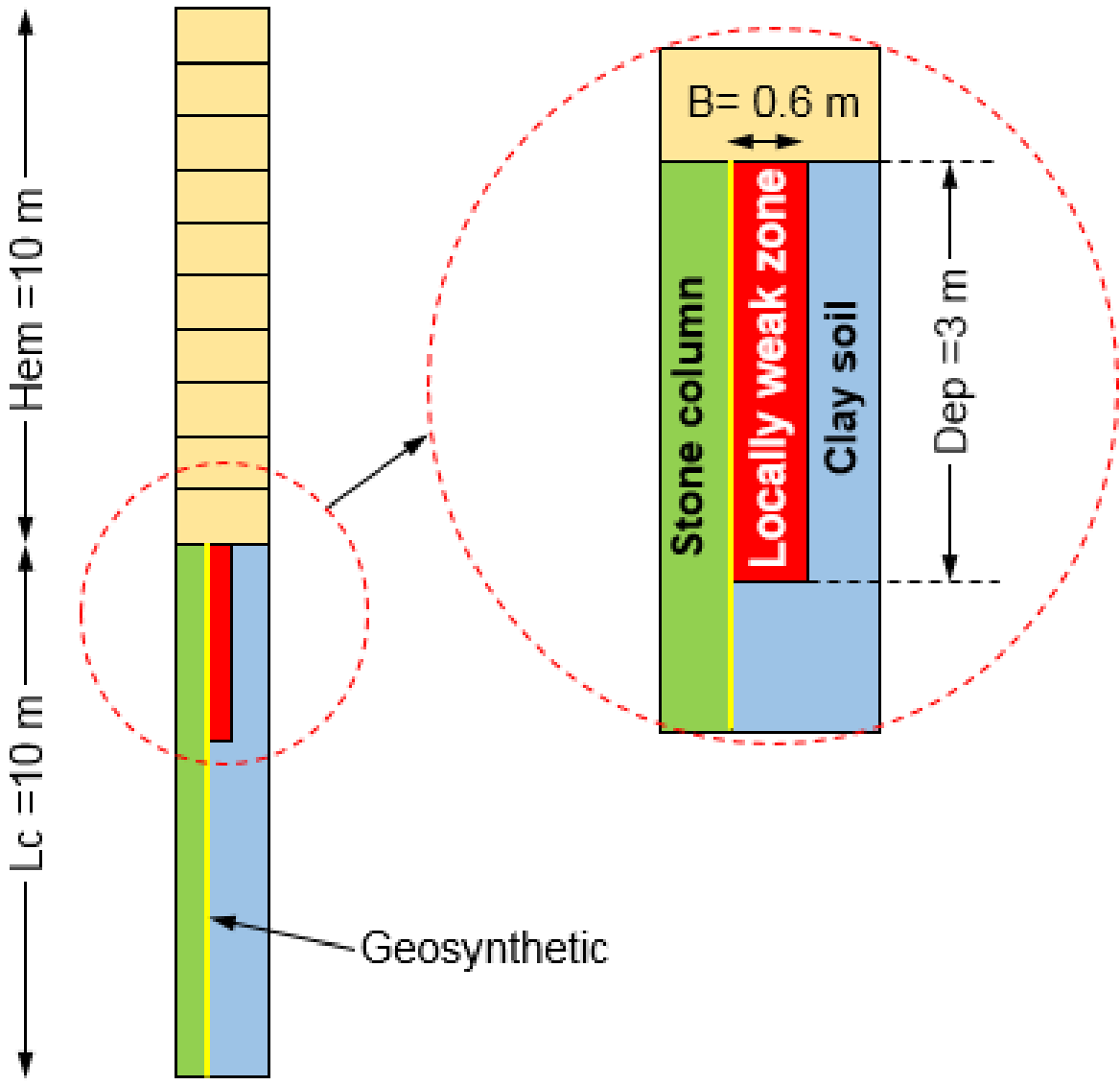

(c)

Figure 3. Finite-element axisymmetric simulation of the geosynthetic-encased column in the unit cell concept. (a) Boundary condition and finite-element mesh, (b) Scheme of ESC adopted in numerical analyses without the locally weak zone, (c) Scheme of ESC adopted in numerical analyses with locally weak zone. 
Table 1. Parameters of materials used in the numerical analysis

\begin{tabular}{|c|c|c|c|c|}
\hline Material properties & Soft clay & Stone column & Embankment & Locally weak zone \\
\hline Material model & HS & $\mathrm{M}-\mathrm{C}$ & $\mathrm{M}-\mathrm{C}$ & SSM \\
\hline$\gamma_{\mathrm{sat}}\left(\mathrm{kN} / \mathrm{m}^{3}\right)$ & 16 & 19 & 22 & 18 \\
\hline $\mathrm{E}^{\prime}(\mathrm{kPa})$ & - & 45000 & 42000 & - \\
\hline$\varphi^{\prime}\left(^{\circ}\right)$ & 23 & 39 & 35 & 5 \\
\hline$\psi\left({ }^{\circ}\right)$ & 0 & 5 & 0 & 0 \\
\hline $\mathrm{c}^{\prime}(\mathrm{kPa})$ & 7 & 0 & 6 & 5 \\
\hline$v^{\prime}$ & 0.2 & 0.3 & 0.33 & - \\
\hline $\mathrm{E}_{50}{ }^{\text {ref }}(\mathrm{kPa})$ & 2313 & - & - & - \\
\hline $\mathrm{E}_{\text {oed }}{ }^{\text {ref }}(\mathrm{kPa})$ & 1850 & - & - & - \\
\hline $\mathrm{E}_{\mathrm{ur}}^{\mathrm{ref}}(\mathrm{kPa})$ & 6938 & - & - & - \\
\hline $\mathrm{c}_{\mathrm{c}}$ & - & - & - & 6 \\
\hline $\mathrm{c}_{\mathrm{s}}$ & - & - & - & 0.6 \\
\hline $\mathrm{e}$ & - & - & - & 3 \\
\hline $\mathrm{P}^{\mathrm{ref}}(\mathrm{kPa})$ & 100 & - & - & - \\
\hline OCR & 1 & - & - & - \\
\hline $\mathrm{K}_{0}$ & 0.6 & 0.37 & 0.43 & 0.91 \\
\hline m (power) & 1 & - & - & - \\
\hline
\end{tabular}

\subsection{Verification of the Finite Element Model}

The numerical model of the finite-element was verified by (PLAXIS) software with analytical methods (AM) and (FEM). The variation in settlement and radius (of the column) with embankment height, are shown in Figure 4 (a and b) with (AM), and 5 (a and b) with (FEM).

Figure 4a shows the comparison between the results of analytical methods and the present finite element study. The comparison was made through the relation between variations in the settlement on the top of the encased stone column plotted against embankment height (Hemb). Therefore, the settlements estimated by Pulko et al. [24] (PEA) are in good agreement with the once in the current study. The maximum values of radius variation under different embankment heights estimated by Raithel \& Kempfert [22] (R\&K), Figure 4b shows good agreement with that of the current study. On the other hand, Pulko et al. [24], and Zhang \& Zhao [35] (Z\&Z) led to an underestimation and an overestimation of the radius, respectively. The maximum radius variation values of Zhang \& Zhao [35] up to an embankment height of $2 \mathrm{~m}$, are closer to those of the current study. This indicates that the present study confirms the hypothesis of Pulko et al. [24] in the settlement and Raithel \& Kempfert [22] in the variation of the radius.

In this section, the obtained values using finite element analysis of maximum radius variation, and settlement at the top of the encased stone columns, were compared with the FEM obtained from Alkhorshid et al. [39]. The comparison is plotted in Figure 5 and it is clear that the current study results are in good agreement with the maximum values of radius variation, and vertical settlement of the study carried out by Alkhorshid et al. [39]. The agreement between the current study and Alkhorshid et al. [39], is satisfactory for values of embankment heights up to $6 \mathrm{~m}$, as shown in Figure 5b. Therefore, the adopted numerical analysis methods can be used to ascertain further the behavior of the stone column on locally weak zone. 

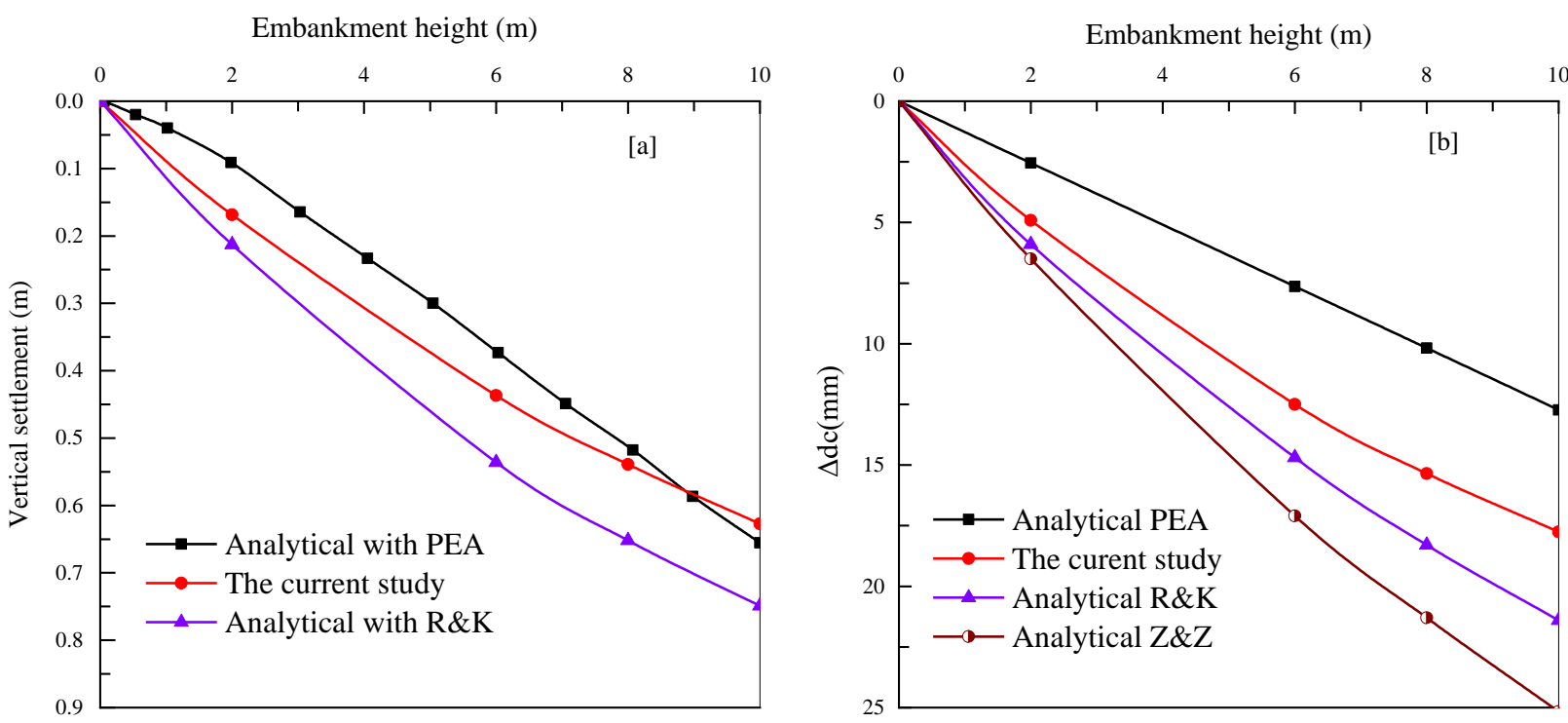

Figure 4. (a) Settlement at the tops of the encased stone column, (b) Maximum radius variation
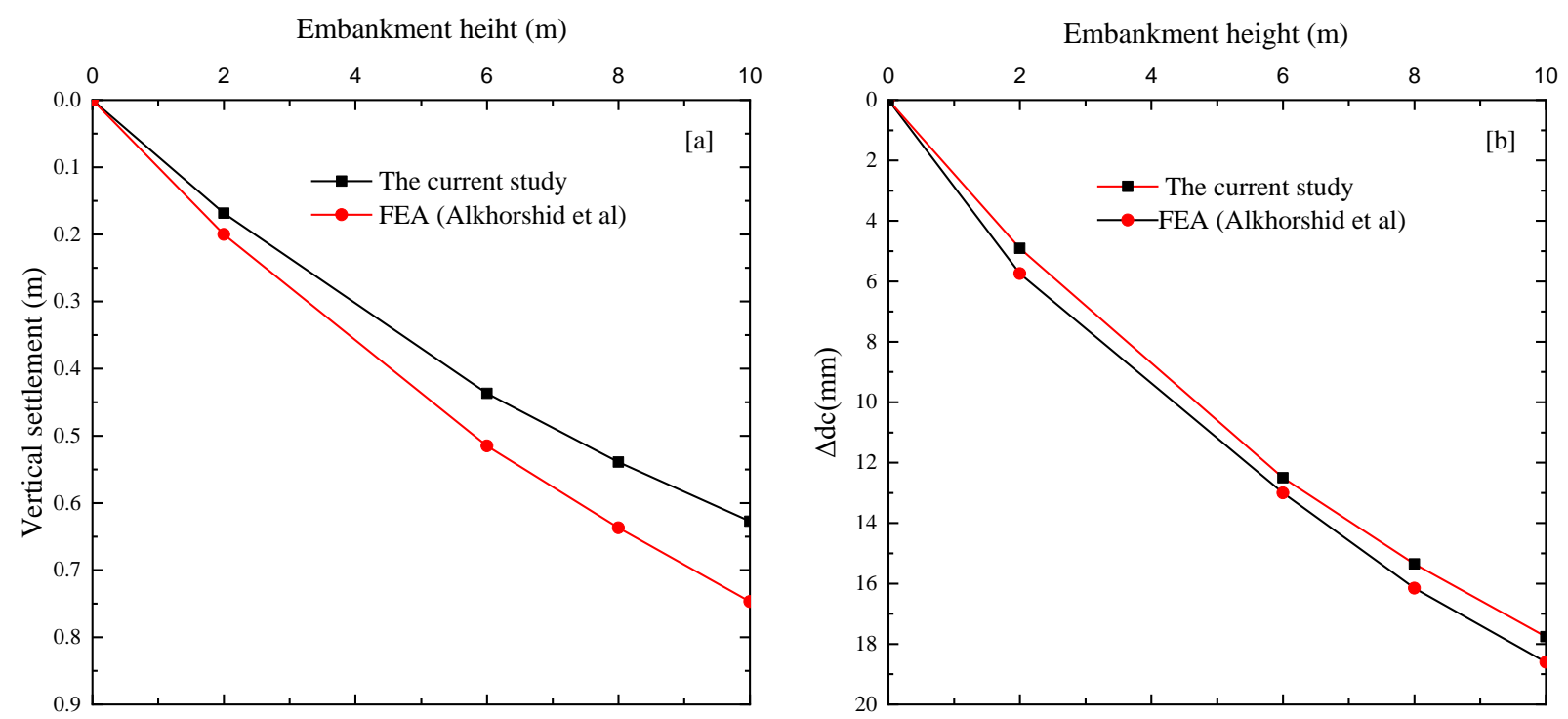

Figure 5. (a) Settlement at the tops of the encased stone column, (b) Maximum radius variation

\section{Results and Discussions}

The numerical analyses were conducted to simulate the construction of embankment on ordinary stone column (OSC) and encased stone column (ESC), the behavior improvement is determined based on the decrease in stone column settlement and decrease in lateral deformation of the stone column with and without locally weak zone (Sabkha soil).

\subsection{Settlement and Lateral Deformation}

Figure 6 shows the variation of the settlement on the top of the column plotted against embankment height (Hemb) for the two cases (with and without locally weak zone). Figure 6a shows the difference in the settlement between the locally weak zone $(L W Z)$ and non-locally weak zone for ordinary stone column. The settlement values are $1.56 \mathrm{~m}$ and $0.736 \mathrm{~m}$ respectively. In comparison with the encased stone column, the settlement of the encased stone column decreased by $0.962 \mathrm{~m}$ in the locally weak zone and $0.627 \mathrm{~m}$ in the case of the non- locally weak zone as shown in Figure 6b. Predicted values of settlement variation are significantly influenced by the embankment height. Furthermore, the large difference between the values of settlements is due to the decrease in the shear strength of the locally weak zone (Sabkha soil).

Figure 7 shows the variation of the lateral deformation observed along the length of the stone column for with and without locally weak zone. Figure 7 a shows that the large lateral deformation at the top portion of the column in the two cases of the ordinary stone column is $221.16 \mathrm{~mm}$ and $31.43 \mathrm{~mm}$, respectively. Similarly, Figure $7 \mathrm{~b}$ shows reduced 
lateral deformation for the encased stone column with and without locally weak zone to be $42.09 \mathrm{~mm}$ and $17.76 \mathrm{~mm}$ respectively. This explains that Sabkha soil is one of the biggest problems with column installation due to the low shear strength. The lack of lateral support causes large lateral deformation (bulging) in the upper part at locally weak zone (Sabkha soil).

From Figures 6 and 7 it can be concluded that as compared with a stone column without geotextile encasement (OSC), the use of (OSC) in the locally weak zone (Sabkha soil) can be problematic due to the lack of adequate lateral confining pressure, particularly in the upper portion of the column. This typically serves as the prime motivation for using the (ESC).
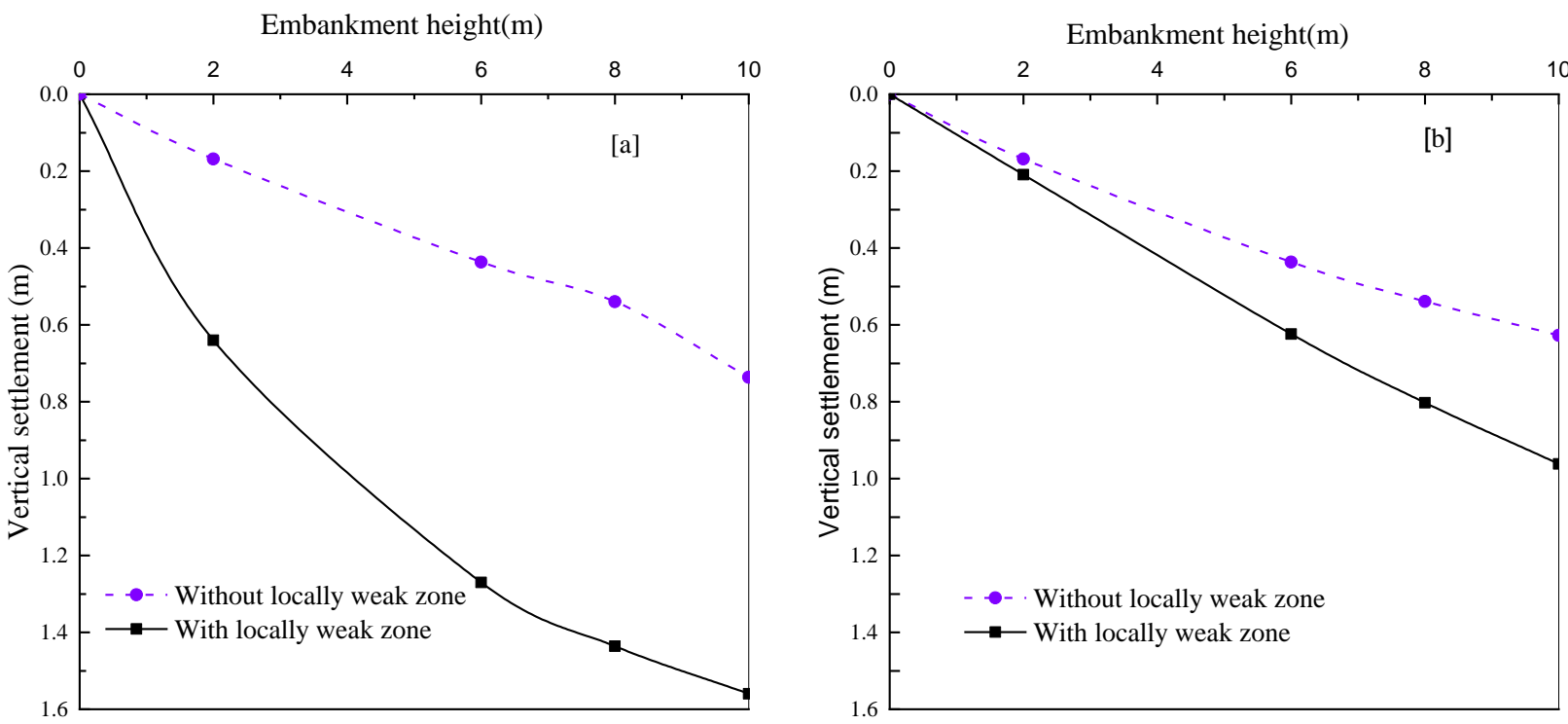

Figure 6. Vertical settlement. (a) Ordinary stone column (OSC), (b) Encased stone column (ESC)
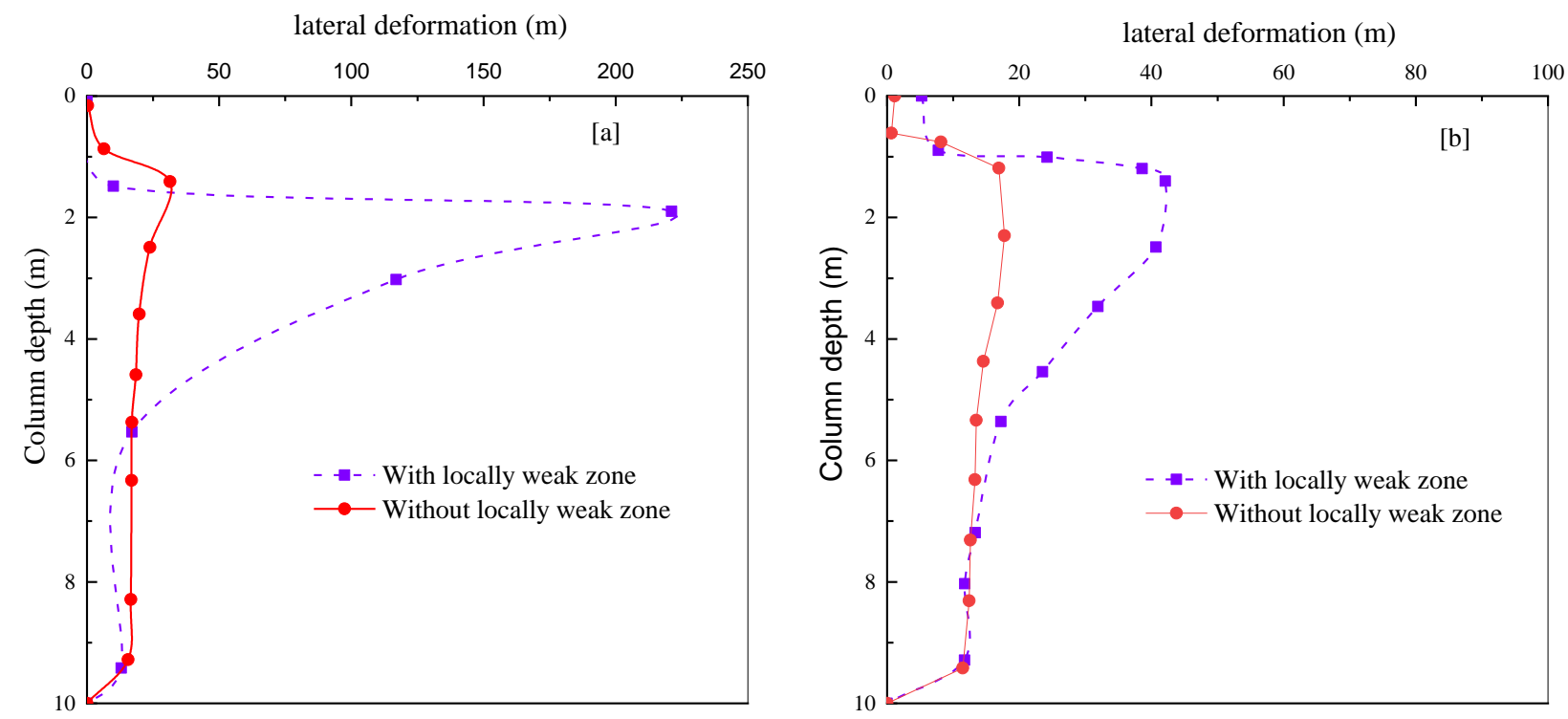

Figure 7. Radius variation. (a) Ordinary stone column (OSC), (b) Encased stone column (ESC)

\subsection{Parametric Study}

In order to investigate the influence of a number of the input parameters on the behavior of the geosynthetic encased stone column with the locally weak zone (Sabkha soil), a series of parametric analyses were performed. In these parameter analyses, basic parameters listed in Table 1 were adopted. 
Table 1. Cases Considered

\begin{tabular}{|c|c|c|}
\hline Category & Description/range & Base values \\
\hline Embankment height, Hemb (m) & $2,6,8,10$ & 10 \\
\hline Encasement stiffness, $\mathrm{J}(\mathrm{kN} / \mathrm{m})$ & $500,1000,2000,4000$ & 2000 \\
\hline Encasement length (m), Lenc & $4,6,8$, full encasement & 10 \\
\hline Influence of Sabkha Layer Thickness Dep & $1.5,3,6$ & 3 \\
\hline Area replacement ratio, ARR \% & $8.16,12.75,18.36$ & 8.16 \\
\hline Friction Angle of Stone-Column Materials & $30,39,45$ & 39 \\
\hline
\end{tabular}

\subsubsection{Effect of Embankment Height}

Figure 8a shows the lateral deformation of the column as a function of the depth for different values of the height of the embankment (Hemb). The results show an increase in the lateral deformation consequent with the increase in the height of the embankment. Increasing the height of the embankment increases the vertical stress above the columns and the compressible soil (Sabkha soil). The consequence is an increase in the horizontal stress exerted on the encased stone columns where for embankment heights of 10, 8, 6, and $2 \mathrm{~m}$, the lateral deformations are 42.09, 34.34, 25.90, and $7.27 \mathrm{~mm}$, respectively.

This explains that increase of the height of the embankment increases the lateral deformation of the column which is consistent with the findings of Raithel and Kempfert (2000) and Alkhorshid et al. (2018) [22, 39]. As we could note, the bulging zone moves downward, as the embankment height increases, where the value of the bulging depth $\left(\mathrm{z}_{\mathrm{b}}\right)$ at a height of $2 \mathrm{~m}$ with the maximum bulging occurring 1D below the top of the encased stone column. At a height of $6 \mathrm{~m}$, the maximum bulging was $1.12 \mathrm{~m}$ which is equivalent to 1.4 of the diameter of the stone column (D), similarly at height of $8 \mathrm{~m}$ maximum bulging was $1.27 \mathrm{~m}$ which is equivalent to 1.58D. Furthermore, at $10 \mathrm{~m}$ height, $1.40 \mathrm{~m}$ equal $1.75 \mathrm{D}$ was obtained as the maximum bulging. A similar phenomenon was observed [22].

Figure $8 \mathrm{~b}$ shows the vertical settlement distributed at the surface for a distance from the stone column centerline to the outer edge of the unit cell as a function of the height of the embankment (Hemb), where Hemb was varied between 2 and $10 \mathrm{~m}$. It should be noted that the effect of embankment height is very important for the stability of the embankment, thus, increasing the height of the embankment increases the load applied to the compressible soil (Sabkha soil). The value of the settlement at the height of 2 and $6 \mathrm{~m}$ is estimated to be 0.26 and $0.65 \mathrm{~m}$, respectively. As for the height, 10 and $8 \mathrm{~m}$ the estimated settlement are 0.99 and $0.83 \mathrm{~m}$, respectively. The settlement increases with increasing height of the embankment.
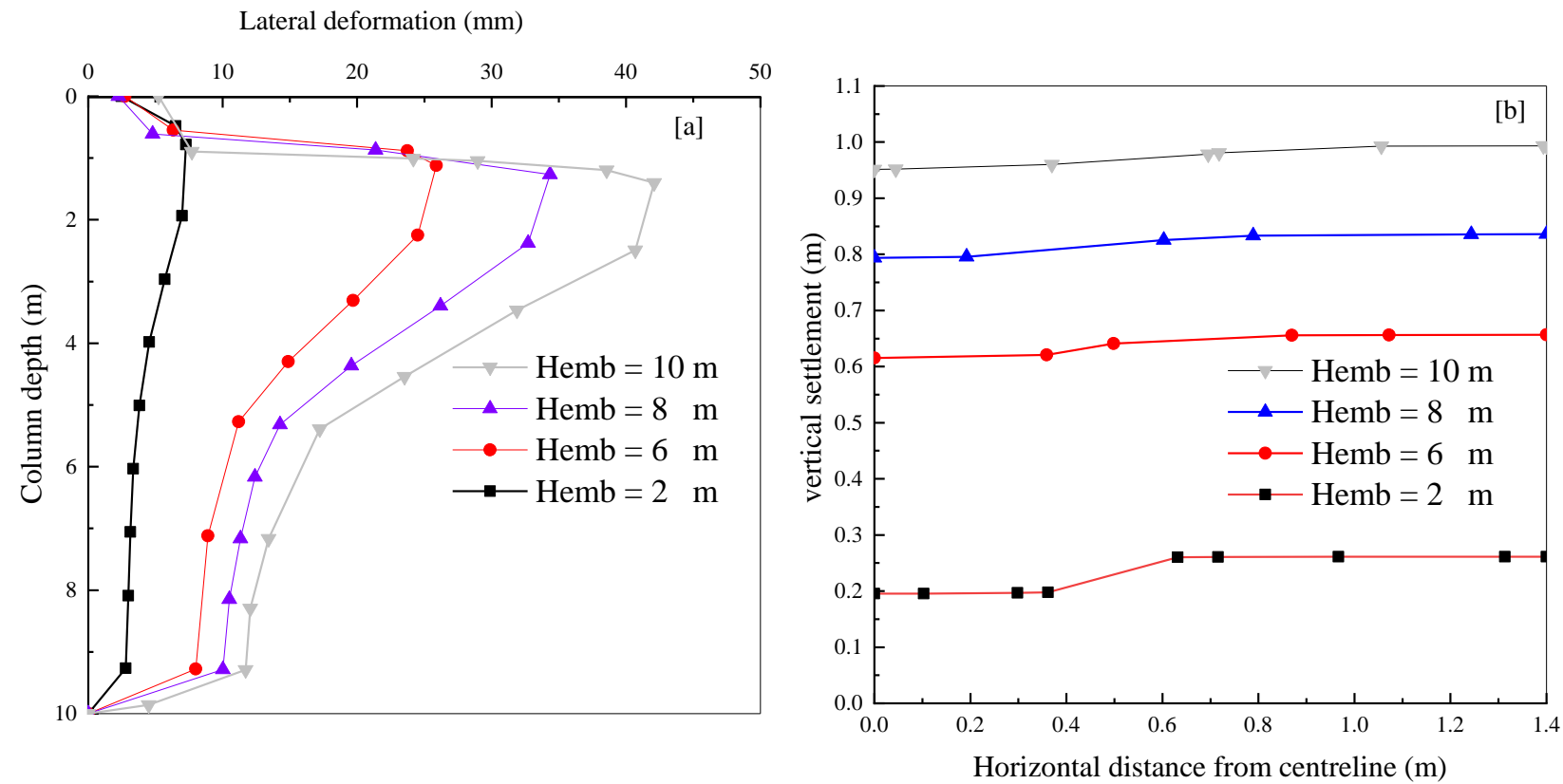

Figure 8. (a) Lateral deformation of the column as a function of the depth for different values of the height of the embankment (Hemb), (b) Vertical settlement distributed at the surface for a distance from the stone column centerline to the outer edge of the unit cell as a function of the height of the embankment (Hemb). 


\subsubsection{Influence of the Stiffness of Geosynthetic Encasement}

The influence of the tensile stiffness of the geosynthetic used for encasement on the performance of the stone column has been investigated numerically [39-41]. In this present study, the effect of the stiffness of an encased stone column was examined by choosing four different values of tensile strength different from 500, 1000, 2000, and 4000 $\mathrm{kN} / \mathrm{m}$. As compared with a stone column without geotextile encasement (OSC), the use of (OSC) in the locally weak zone (Sabkha soil) can be problematic, as it was mentioned previously, due to the lack of adequate lateral confining pressure, particularly in the upper portion of the column. This typically serves as the prime motivation for using (ESC).

The effect of geosynthetic encasement is clearly illustrated in Figure 9a, as the (OSC) exhibited considerable lateral bulging, as much as $221.16 \mathrm{~mm}$, the lateral deformation at the top of the column is reduced by $60.73,68.83,80.96$ and $89.60 \%$ when the column is encased in geotextile with the stiffness of $\mathrm{J}=500,1000,2000$, and $4000 \mathrm{kN} / \mathrm{m}$, respectively. However, it should be noted that this large difference between the values of lateral deformation of ordinary stone columns (OSC) and geotextile encased stone columns are due to the low shear strength in the locally weak zone.

Since when installing the stone column, it does not find any lateral force in this zone, as we observe in Figure 9b, the beneficial effect of geotextile encasement on the reduction of maximum lateral bulging is also evident in Figure 9c. This confirms that the encased stone columns are very effective in very soft soil [42]. The encasement, besides increasing strength and stiffness of the stone column, prevents a lateral deformation of stones when the column is installed even in extremely soft soils, thus enabling quicker and more economical installation. Encasement material also prevents the mixing of fine-grained soil with stone material, which has a negative effect on the stone column drainage efficiency during the consolidation process.

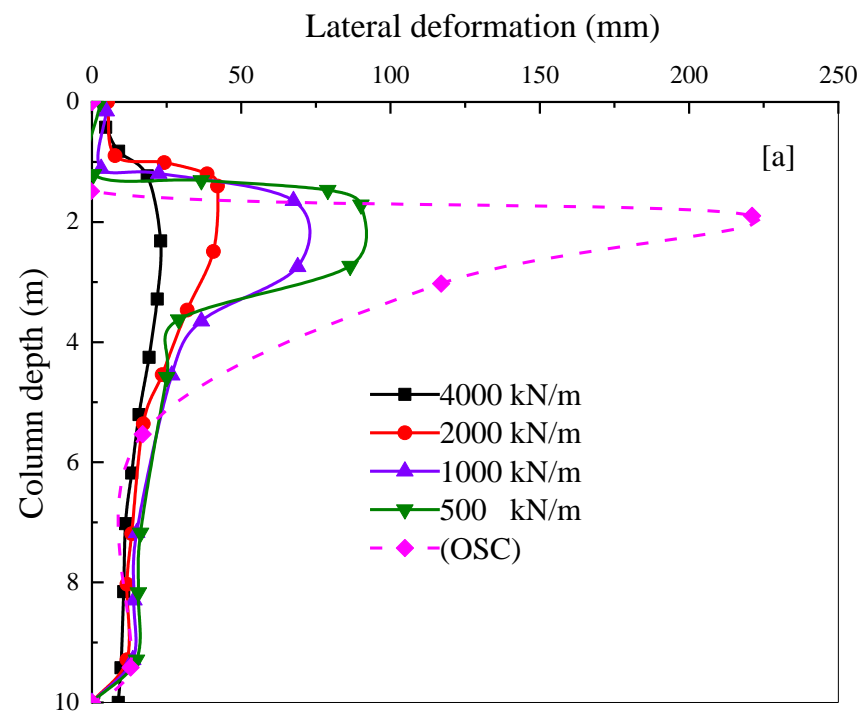

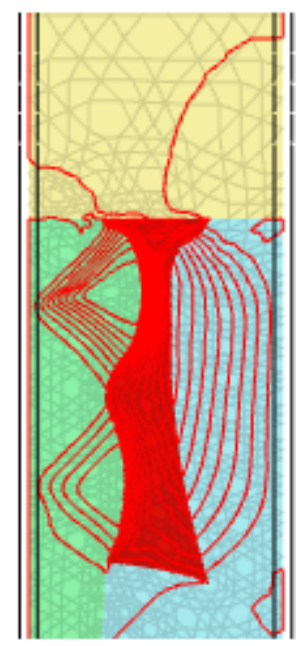

[b]

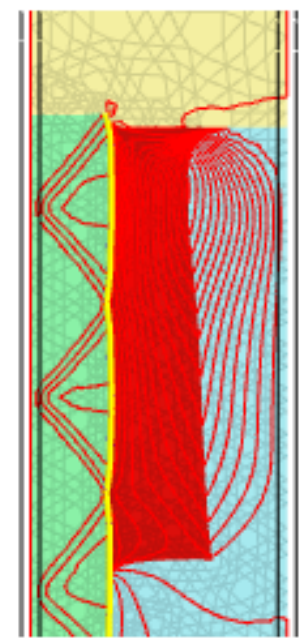

[c]

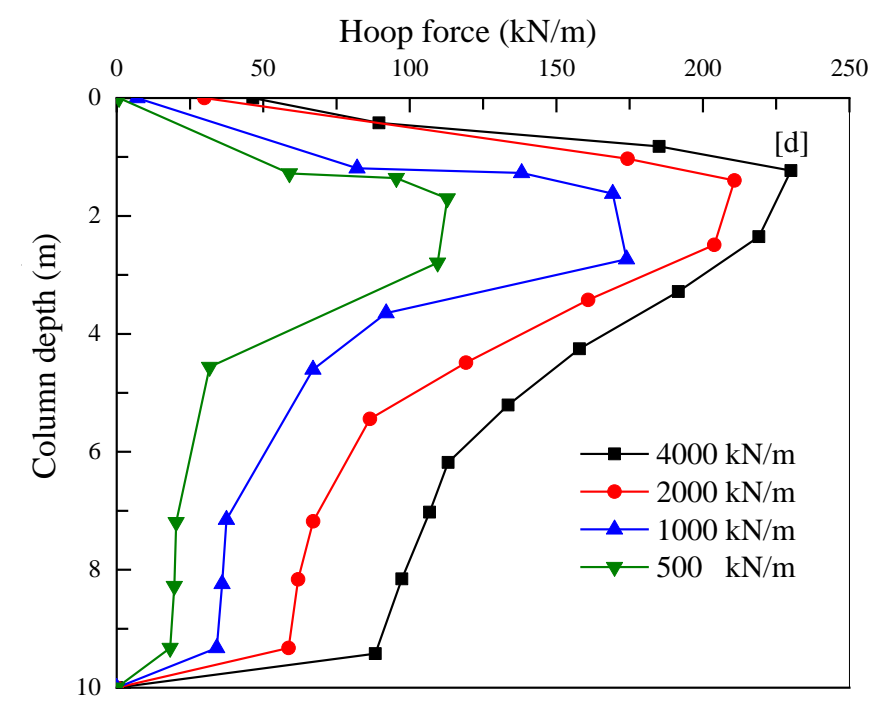

Figure 9. (a) Lateral deformation vs. depth, (b) Deformed for (OSC) modeled by FEM. (c) Deformed for (ESC) modeled by FEM, (d) Hoop force vs. depth with different tensile stiffnesses 
The hoop tension force is a property of geotextile material. Figure 9d shows the relationship between geotextile stiffness and hoop tension force. It can be seen that, by increasing geotextile stiffness, the value of the hoop tension force increased. The hoop tensions obtained are 109.52, 173.97, 210.80, and $230.03 \mathrm{kN} / \mathrm{m}$ for geotextile Ringtract 500 , 1000, 2000, and $4000 \mathrm{kN} / \mathrm{m}$, respectively. The same was observed by Murugesan and Rajagopal [31] and it may be observed that hoop force in geotextile follows a variable pattern with depth.

When the encased stone column reinforced ground is loaded, concentration of stress occurs in the stone column, and an accompanying reduction in vertical stress occurs in the surrounding less stiff soil (Sabkha), Figure 10 shows the difference in vertical stress on top of the encased column and the soft soil. It was observed that with stiffness of $\mathrm{J}=0$, $500,1000,2000$, and $4000 \mathrm{kN} / \mathrm{m}$ vertical stress in the encased stone column was 171.32, 261.51, 503.52, 933, and $1826.36 \mathrm{kPa}$, respectively. However, in surrounding soil the vertical stress was $169.81,152.20,128.32,90.13,48.45$ $\mathrm{kPa}$. This is further illustrated in Figure 10 (b \& c).

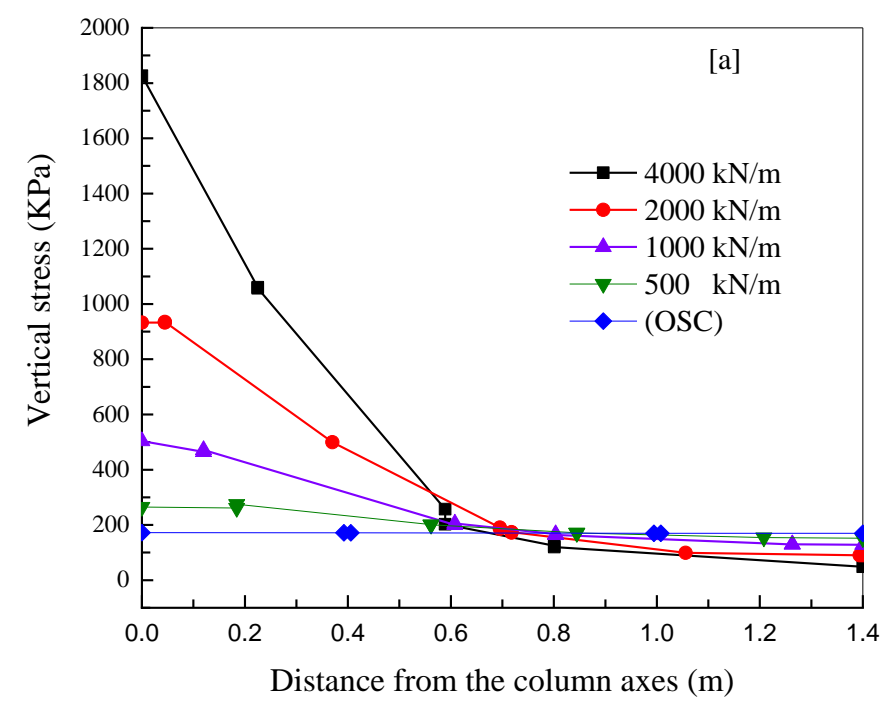

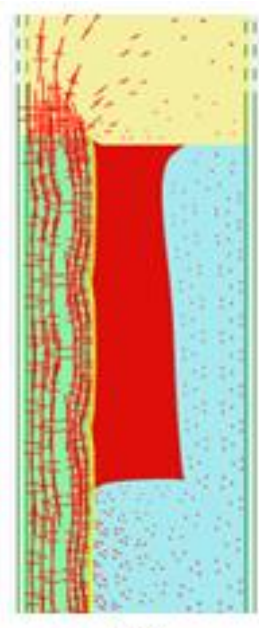

[b]

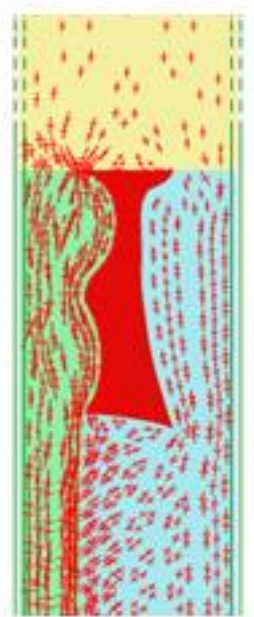

[c]

Figure 10. (a) Vertical stress on top of the encased column and the soft soil, Effective stress distribution: (b) Encased stone column $(\mathrm{J}=2000 \mathrm{kN} / \mathrm{m})$, (c) Ordinary stone column

Figure 10 (b \& c) shows the effective stress distributions as cross marks. When it comes to the ordinary stone columns (OSC), these cross marks in the surrounding soil are visibly greater than those for the encased column, which means that a higher share of vertical stress goes to surrounding soil, this is consistent with the findings of Alkhorshid et al. (2018) [39].

\subsubsection{Effect of Encasement Length}

Figure 11 a shows the distribution of the lateral bulging of the encased stone column through its depth using different encasement depths from 4 to $10 \mathrm{~m}$ (fully encased), tensile strength $(\mathrm{J}=2000 \mathrm{kN} / \mathrm{m})$. When the stone column is partially encased at a certain depth (ideal depth), it's bulging in the encased zone is slightly smaller than that of the full-encased column case. However, the non-encased zone has higher values of the column bulging (encasement depths less than $6 \mathrm{~m}$ ). The non-encased zone in the column starts with a maximum value that generates a largely differentially lateral bulging at the endpoint of the encasement in the encasement depths $4 \mathrm{~m}$. In Figure 11 the lateral bulging values decrease gradually with depth until it reaches zero at the column base. The shallower the encasement depth is, the higher the lateral bulging values in the non-encased zone of the stone column are. Hence, this analysis shows that the length required for the encasement to limit both the settlement and especially the bulging depends on the depth of the locally weak layer. The encasement should just go beyond the weak area. As illustrated in Figure 11a, at the length of the encasement 4, 6, 8, $10 \mathrm{~m}$ (fully encased), the bulging value is 58.13, 41.24, 41.99, and 42.09 mm, respectively.

Settlement ratio $\beta$, the ratio of the settlement of ESC to that without encasement (OSC), is defined as $\beta=$ $\left(\mathrm{S}_{\mathrm{ESC}} / \mathrm{S}_{\mathrm{OSC}}\right)$. In Figure $11 \mathrm{~b}$, the settlement ratios $\beta$ are plotted against the encasement length. When increasing the length of the encasement, we notice a decrease in the settlement ratios. For length of the encasement 4, 6, 8, and $10 \mathrm{~m}$ (fully encased), the ratio of settlement values are $0.75,0.70,0.68$, and 0.66 , respectively. This shows that the encasement length is important in decreasing the settlement. 

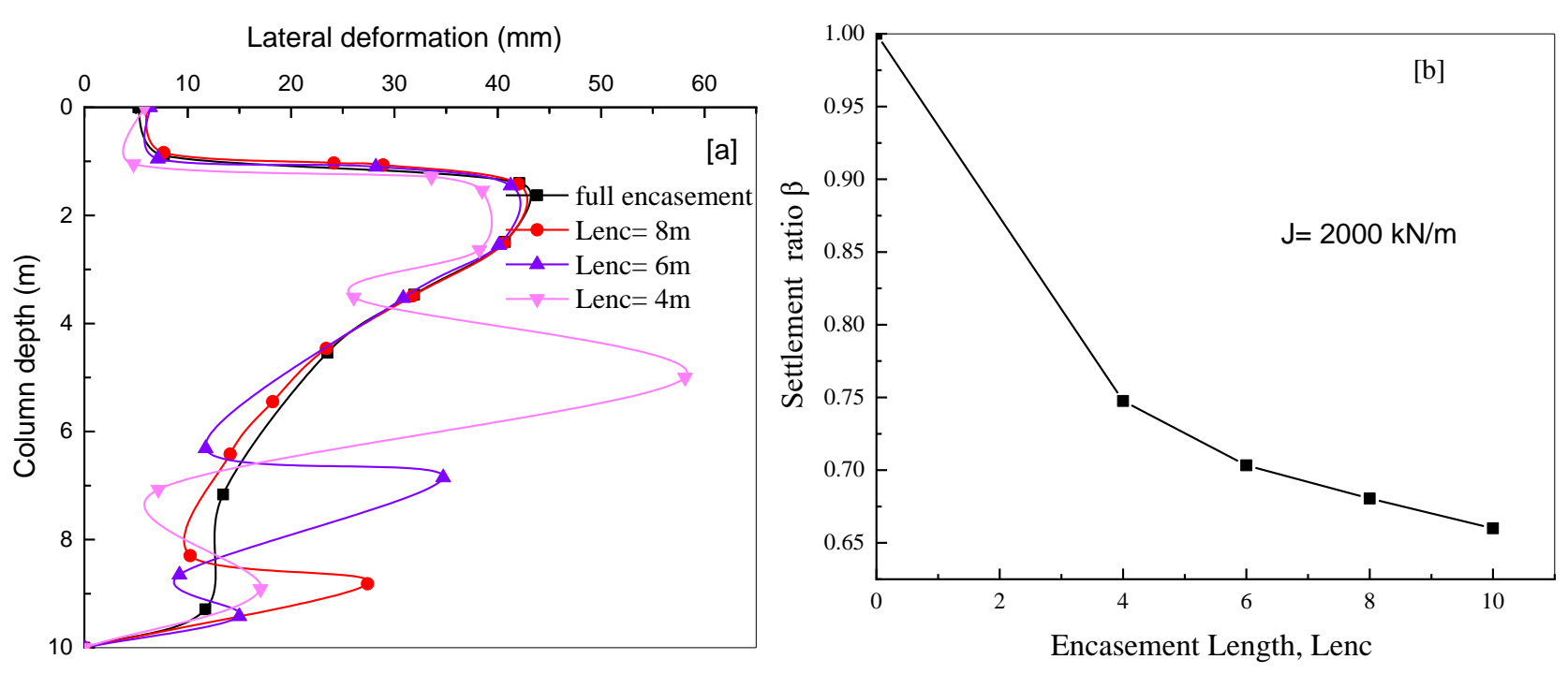

Figure 11. (a) Distribution of the lateral bulging of the encased stone column through its depth, (b) Ratio of settlement vs. Encasement length (Lenc)

\subsubsection{Influence of Sabkha Layer Thickness}

Figure 12 shows the effect of the Sabkha layer thickness on the encased stone column for the vertical settlement. There is an increase in the vertical settlement consequent with the increase in the Sabkha layer thickness, as we notice in Figure 12, vertical settlements for Sabkha depths of 1.5, 3, and $6 \mathrm{~m}$ are 0.89, 0.99, $1.18 \mathrm{~m}$, respectively. It can be concluded from here that the depth of the Sabkha layer has a major impact on the instability of the embankment.

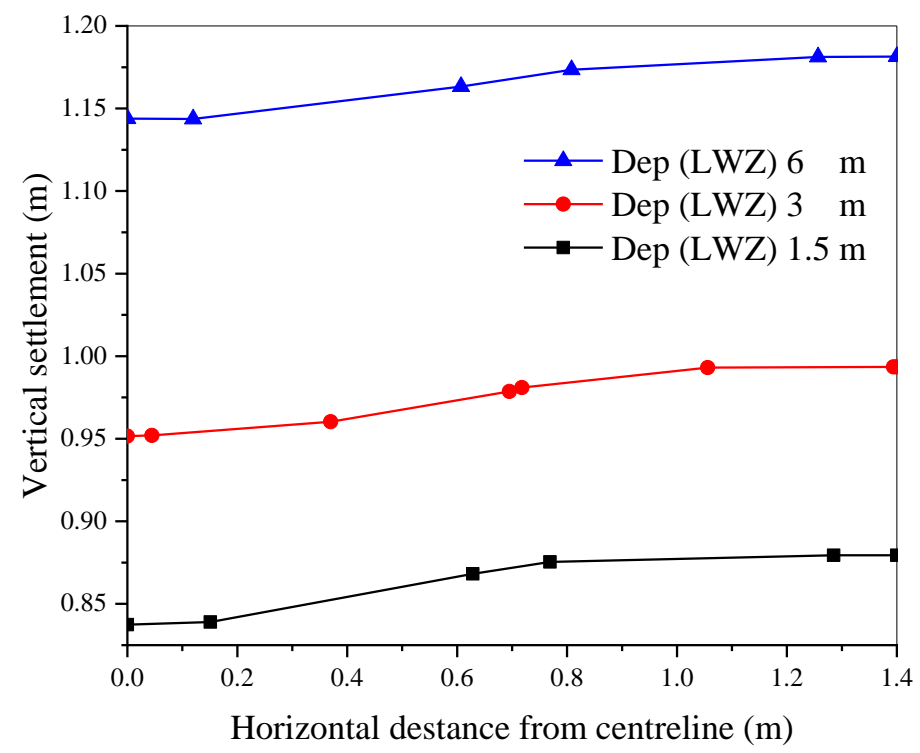

Figure 12. Influence of the depth of locally weak zone on the settlement at the embankment base

\subsubsection{Influence of Area Replacement Ratio (ARR) on the Performance of ESC}

The effect of area replacement ratio on settlement ratio is better illustrated with the degree of improvement in the Sabkha soil that is realized through the use of any type of ground improvement technique, a parameter called the settlement ratio $(\beta)$ is commonly used. The settlement ratio is defined, as mentioned above, as the ratio of the settlement of the encased stone column (ESC) to the settlement ordinary stone column (OSC). The lower the value of $(\beta)$, the better the performance realized due to ground improvement. Collin [43] stated that the ARR should be selected to be between 10 and $20 \%$ for the preliminary design of (ESC). To investigate the effect of variations in the ARR have on (ESC) response, three (ESC) were modelled with ARR values equal to 8.16, 12.75, and 18.36\%. During these analyses, all other parameters were maintained at their base values.

The variation of settlement ratios $\beta$ versus area replacement ratio with varying encasement stiffness is shown in Figure 13. It was observed that with increasing area replacement ratio, the settlement ratio decreases. For example, for an area replacement ratio varying from $8.16 \%$ to $12.75 \%$, the settlement ratio $(\beta)$ decreases by $14.50 \%$. Similarly, 
between $12.75 \%$ and $18.36 \%$ the settlement ratios $(\beta)$ decreases by $17.72 \%$ for the encasement stiffness of $4000 \mathrm{kN} / \mathrm{m}$. On the other hand, when the encasement stiffness is $2000 \mathrm{kN} / \mathrm{m}$, for an area replacement ratio of $8.16 \%$ to $12.75 \%$, the settlement ratio $(\beta)$ decreases by $13.72 \%$ and, for $12.75 \%$ to $18.36 \%$ the settlement ratio $(\beta)$ decreases by $17.72 \%$. However, the same case for the encasement stiffness $1000 \mathrm{kN} / \mathrm{m}$, for an area replacement ratio of $8.16 \%$ to $12.75 \%$, the settlement ratio $(\beta)$ decreases by $7.81 \%$, and for $12.75 \%$ to $18.36 \%$ the settlement ratio $(\beta)$ decreases by $11.10 \%$. Similarly, for a small value of the encasement stiffness $500 \mathrm{kN} / \mathrm{m}$, for the ARR of $8.16 \%$ to $12.75 \%$, the settlement ratio $(\beta)$ decreases by $8.77 \%$, and for $12.75 \%$ to 18.36 the settlement ratio $(\beta)$ decreases by $4.91 \%$. It can be concluded from this study that with an increase in area replacement ratio associated with an increase in encasement stiffness, the settlement ratio $\beta$ decreases better. Similar observations have been reported by Yoo [41]. This is what is needed in the presence of the locally weak zone (Sabkha soil).

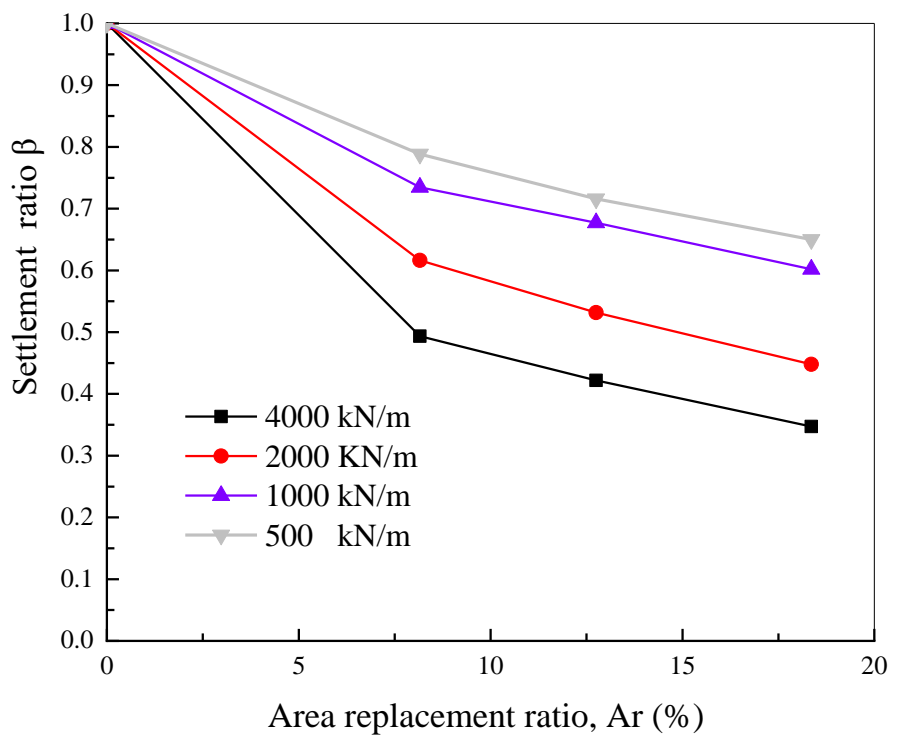

Figure 13. Settlement ratio vs. Replacement ratio

Figure 14 shows the effect of variations in area replacement ratio on the lateral deformation of (ESC) with different values of encasement stiffness $(500,1000,2000$, and $4000 \mathrm{kN} / \mathrm{m})$. For all the analyzed cases, the bulging increases with the increase of the area replacement ratio. For the three area replacement ratios of $8.16 \%, 12.75 \%$, and $18.36 \%$, considered in this study, and with an encasement stiffness of $500 \mathrm{kN} / \mathrm{m}$, the maximum bulging is estimated at 90.48 , 107.7, and $133.33 \mathrm{~mm}$, respectively as shown in Figure 14a. On the other hand, in the case of $1000 \mathrm{kN} / \mathrm{m}$ encasement stiffness, lateral deformation is reduced by values $68.93,70.89$, and $99.026 \mathrm{~mm}$ shown in Figure $14 \mathrm{~b}$. However, in the cases of encasement stiffness of 2000 and $4000 \mathrm{kN} / \mathrm{m}$ the bulging reduces progressively by values 42.09, 48.52, and $37.73 \mathrm{~mm}$ for the stiffness $2000 \mathrm{kN} / \mathrm{m}$, and 21.87, 23, and $24.77 \mathrm{~mm}$ for the stiffness $4000 \mathrm{kN} / \mathrm{m}$, the results are shown in Figures 14c and 14d.
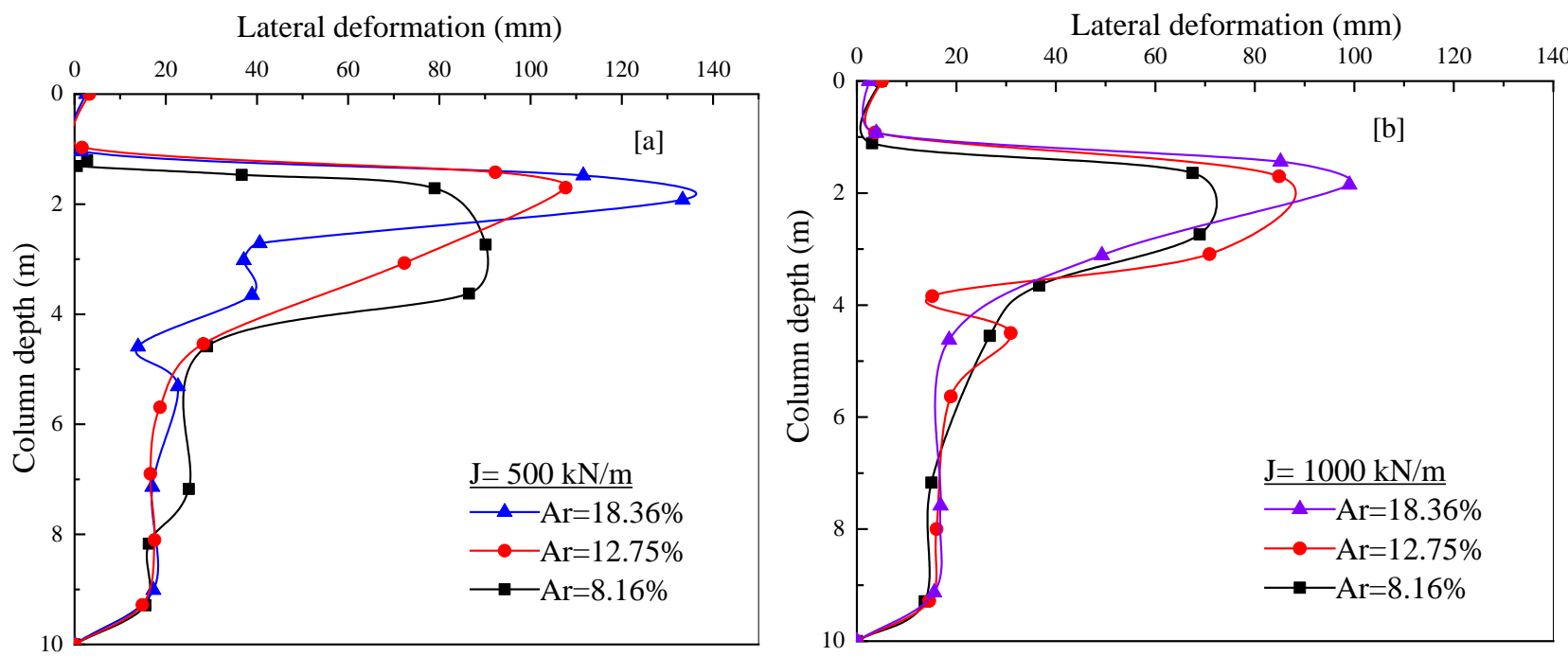

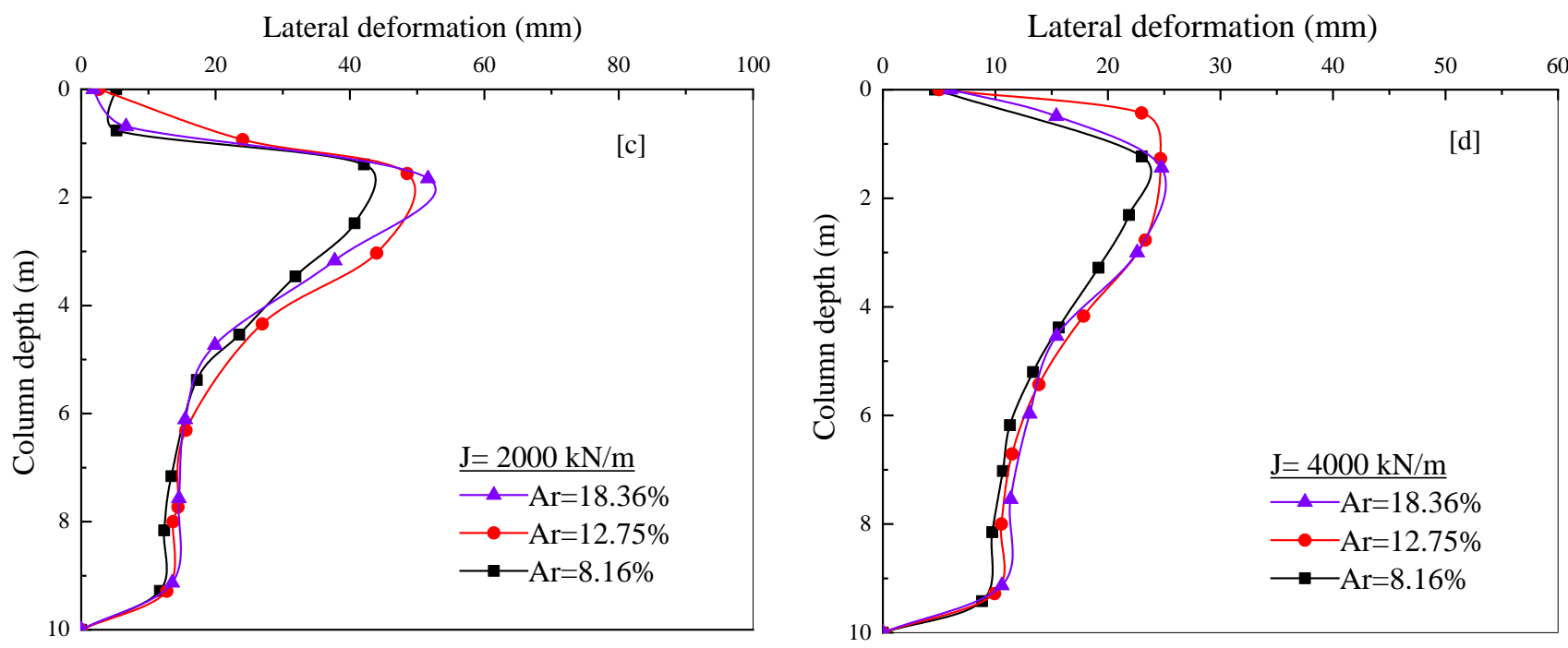

Figure 14. Lateral deformation vs. depth. (a) $\mathrm{J}=500 \mathrm{kN} / \mathrm{m}$, (b) $\mathrm{J}=1000 \mathrm{kN} / \mathrm{m}$, (c) $\mathrm{J}=\mathbf{2 0 0 0} \mathrm{kN} / \mathrm{m}$, (d) $\mathrm{J}=\mathbf{4 0 0 0} \mathrm{kN} / \mathrm{m}$

\subsubsection{Influence of Friction Angle of Stone Column Materials}

In order to study the effect of the friction angle of stone-column materials on the lateral deformation and the vertical settlement of the encased stone column, we performed analyses with a series of three friction angles $\left(30^{\circ}, 39^{\circ}\right.$, and $\left.45^{\circ}\right)$.

Figure 15a shows the lateral deformation of the column as a function of the depth for different angles of the friction of the stone column material. It can be seen that the higher the friction angle value, the lesser the lateral deformation. The difference between the lateral deformation of angle $30^{\circ}$ and angle $39^{\circ}$ is estimated to $7.6 \mathrm{~mm}$, and this difference between angle $\left(39^{\circ}, 45^{\circ}\right)$ is $4.82 \mathrm{~mm}$. This shows that the friction angle of the stone column has an important role in reducing lateral deformation.

The results indicated that the efficiency of ESC is better if the column material is compacted well to achieve a high friction angle. This is consistent with the findings presented by Alkhorshid et al. [39]. As explained in the previous section, the friction angle of (ESC) is also critical to enhancing the settlement response of the column and the soil. Figure 15b shows the time as a function of settlement, for different friction angles of the column, where we can note that the increase in the angle of friction of the column will decrease the settlement. For the friction angle of $30^{\circ}, 39^{\circ}$ and $45^{\circ}$, the estimated settlement is $1.10 \mathrm{~m}, 0.99 \mathrm{~m}$ and $0.91 \mathrm{~m}$ respectively. The angle of friction for the stone column is important in reducing settlement especially in the presence of the locally weak zone.
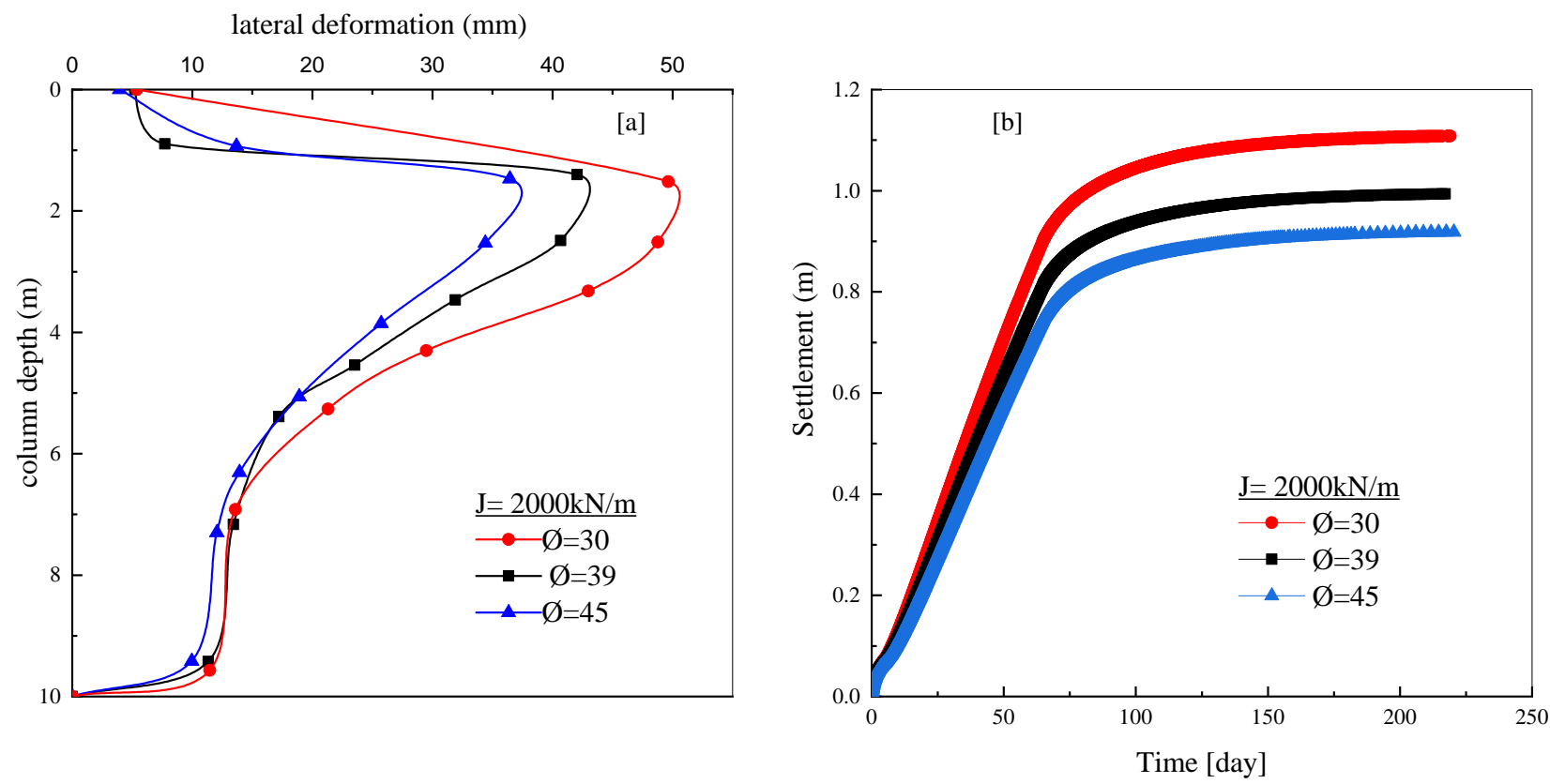

Figure 15. Response of stone column with varying friction Angle of encased stone column. (a) Maximum lateral deformation of stone column, (b) Settlement at top of stone column and surrounding soil 


\section{Conclusions}

This research studies the behavior of embankments supported by encased stone columns in locally weak zones. Several numerical simulations were performed to analyze the effect of $(L W Z)$ on columns with respect to lateral deformation, settlement behavior, and stress distribution between the stone column and the soil surrounding the column. According to the results obtained from the present study, the following conclusions are made:

- It has been demonstrated that ordinary stone columns (OSC) were ineffective to support the embankment due to excessive bulging $(221.16 \mathrm{~mm})$ caused by the lack of lateral pressure. On the other hand, the encased stone columns (ESC) showed good behavior, namely a much reduced bulging $(42.09 \mathrm{~mm})$ and a reasonable settlement (0.962 m vs. $1.560 \mathrm{~m}$ for an OSC) so that it is possible to build safe very high embankments.

- The numerical analysis also shows that the length of the encasement should just be greater than the depth of the LWZ. This means that the encasement length is not required to a depth that equals the depth of the stone column. The value of the lateral deformation is $41.24 \mathrm{~mm}$ for an encasement length of $6 \mathrm{~m}, 41.99 \mathrm{~mm}$ for an encasement length of $8 \mathrm{~m}$, and $42.09 \mathrm{~mm}$ for a full encasement. For instance, the ideal encasement depth for the present case study is $6 \mathrm{~m}$ (60\% from full encasement).

- The area replacement ratio (ARR) leads to two opposite effects. On the one hand, it decreases the value of settlement ratio $(\beta)$, but on the other hand, it decreases the effectiveness of the encasement by increasing the lateral deformations.

- Furthermore, this numerical analysis has shown that the increase in the internal friction angle of the stone column material leads to an increase in the resistance of the column against failure and, consequently, the lateral deformations and settlements of the column decrease in $(L W Z)$. For example, for the friction angle of $30^{\circ}, 39^{\circ}$ and $45^{\circ}$, the estimated settlement is $1.10 \mathrm{~m}, 0.99 \mathrm{~m}$ and $0.91 \mathrm{~m}$ respectively.

- The reduction in differential settlements is sensitive to the geometry of the locally weak zone, increasing in the depth of $(L W Z)$ results in increases in the settlement of the column.

- Increasing the height of the embankment increases the vertical stress above the column and the compressible soil (Sabkha soil). The consequence is an increase in the horizontal stress exerted on the encased stone column. On the other hand, the depth of radial bulge is affected by the height of the embankment, as it increases with the height of the embankment increases.

- Increase in the stiffness of the geosynthetic encasement of stone columns leads to increases in the column stiffness, the hoop tension force mobilized in the encasement, and the lateral confinement provided to the stone column. Where the hoop strains in the geosynthetic encasement are at a maximum near the top surface and decrease with depth. The stone column encasement causes reducing the total stress in the soft soil along with consolidation.

Although the conclusions that are reached in this study cannot necessarily be generalized to all cases with different geometries and soil/geosynthetic properties, they do provide a useful indication of general trends in behavior of embankments supported by encased stone columns in locally weak zones so that it is possible to build safe very high embankments. Future experimental research is needed in this area to validate the simulation-based observations that are made herein and to better understand the behavior of the columns.

\section{Funding}

Funding by the Ministry of Higher Education and Scientific Research in Algeria. Grant ID: PNE 637-2019/2020.

\section{Acknowledgements}

The authors expressed their acknowledgementand appreciation to the staff of the Department of Civil Engineering, Faculty of Technology, University of Biskra, Algeria.

\section{Conflicts of Interest}

The authors declare no conflict of interest.

\section{References}

[1] Greenwood, D. (1970). "Mechanical improvement of soils below ground surface." Paper presented at the Inst Civil Engineers Proc, London/UK/.

[2] Barksdale, Richard D., and Robert Charles Bachus. "Design and construction of stone columns," vol. I. No. FHWA/RD-83/026; SCEGIT-83-104. Turner-Fairbank Highway Research Center, (1983). 
[3] Karkush, Mahdi O, and Anwar Jabbar. "Improvement of Soft Soil Using Linear Distributed Floating Stone Columns Under Foundation Subjected to Static and Cyclic Loading." Civil Engineering Journal 5, no. 3 (March 19, 2019 ): 702. doi:10.28991/cej-2019-03091280.

[4] Mohtasham, Mohammad Reza, and Mahdi Khodaparast. "Investigation of the Effect of Dimensional Characteristics of Stone Column on Load-Bearing Capacity and Consolidation Time.” Civil Engineering Journal 4, no. 6 (July 4, 2018 ): 1437. doi:10.28991/cej-0309184.

[5] Murugesan, S., and K. Rajagopal. "Model Tests on Geosynthetic-Encased Stone Columns." Geosynthetics International 14, no. 6 (December 2007): 346-354. doi:10.1680/gein.2007.14.6.346.

[6] Abusharar, Sari W., and Jie Han. "Two-Dimensional Deep-Seated Slope Stability Analysis of Embankments over Stone Column-Improved Soft Clay.” Engineering Geology 120, no. 1-4 (June 2011): 103-110. doi:10.1016/j.enggeo.2011.04.002.

[7] Choobbasti, A. J., A. Zahmatkesh, and R. Noorzad. "Performance of Stone Columns in Soft Clay: Numerical Evaluation." Geotechnical and Geological Engineering 29, no. 5 (May 18, 2011): 675-684. doi:10.1007/s10706-011-9409-x.

[8] Madhav, M. R., and P. P. Vitkar. "Strip Footing on Weak Clay Stabilized with a Granular Trench or Pile." Canadian Geotechnical Journal 15, no. 4 (November 1, 1978): 605-609. doi:10.1139/t78-066.

[9] Brauns, J. "Die anfangstraglast von schottersäulen im bindigen untergrund.” (1978).

[10] Aboshi, H. "The" Compozer"-a method to improve characteristics of soft clays by inclusion of large diameter sand columns.". Paris. (1979).

[11] A Rashid, Ahmad Safuan, Aliff Ridzuan Bunawan, and Khairun Nissa Mat Said. "The Deep Mixing Method: Bearing Capacity Studies." Geotechnical and Geological Engineering 35, no. 4 (March 10, 2017): 1271-1298. doi:10.1007/s10706017-0196-x.

[12] Sharma, Radhey S, BR Phani Kumar, and G Nagendra. "Compressive Load Response of Granular Piles Reinforced with Geogrids.” Canadian Geotechnical Journal 41, no. 1 (February 1, 2004): 187-192. doi:10.1139/t03-075.

[13] Hasan, Murtaza, and N. K. Samadhiya. "Soft Soils Improvement by Granular Piles Reinforced with Horizontal Geogrid Strips.” International Journal of Geotechnical Engineering 12, no. 1 (November 17, 2016): 101-108. doi:10.1080/19386362.2016.1252139.

[14] Rao, B., and Bhandari, R. "Skirting - a new concept in design of heavy storage tank foundation." Paper presented at the Proceedings of the 6th South-East Conference on soil Engineering, Taipei, Taiwan. (1980).

[15] Juran, I., and Riccobono, O. "Reinforcing soft soils with artificially cemented compacted-sand columns." Journal of Geotechnical Engineering 117, no. 7 (July 1991): 1042-1060. doi:10.1061/(ASCE)0733-9410(1991)117:7(1042).

[16] Van Impe, W., and Silence, P. "Improving of the bearing capacity of weak hydraulic fills by means of geotextiles." International conference on geotextiles (1986): 1411-1416.

[17] Raithel, M., H. G. Kempfert, and A. Kirchner. "Geotextile-encased columns (GEC) for foundation of a dike on very soft soils." In Proc., 7th Int. Conf. on Geosynthetics, vol. 3, Balkema, Rotterdam, Netherlands: GIGSA, (2002): 1025-1028.

[18] Montez, F., and Brasil, H. "First Use Of Geosynthetic Encased Sand Columns In South America.".

[19] Malarvizhi, S. N., and K. Ilamparuthi. "Load versus settlement of clay bed stabilized with stone and reinforced stone columns." In 3rd Asian Regional Conference on Geosynthetics, (2004): 322-329.

[20] Ayadat, T., and A. M. Hanna. "Encapsulated Stone Columns as a Soil Improvement Technique for Collapsible Soil." Proceedings of the Institution of Civil Engineers - Ground Improvement 9, no. 4 (October 2005): $137-147$. doi:10.1680/grim.2005.9.4.137.

[21] Murugesan, S., and K. Rajagopal. "Studies on the Behavior of Single and Group of Geosynthetic Encased Stone Columns." Journal of Geotechnical and Geoenvironmental Engineering 136, no. 1 (January 2010): 129-139. doi:10.1061/(asce)gt.19435606.0000187 .

[22] Raithel, Marc, and Hans-Georg Kempfert. "Calculation models for dam foundations with geotextile coated sand columns." In ISRM International Symposium. International Society for Rock Mechanics and Rock Engineering, (November 2000): 19-24.

[23] Castro, Jorge, and César Sagaseta. "Deformation and Consolidation Around Encased Stone Columns." Geotextiles and Geomembranes 29, no. 3 (June 2011): 268-276. doi:10.1016/j.geotexmem.2010.12.001.

[24] Pulko, Boštjan, Bojan Majes, and Janko Logar. "Geosynthetic-Encased Stone Columns: Analytical Calculation Model." Geotextiles and Geomembranes 29, no. 1 (February 2011): 29-39. doi:10.1016/j.geotexmem.2010.06.005. 
[25] Zhang, Yiping, Tao Li, and Yang Wang. "Theoretical Elastic Solutions for Foundations Improved by Geosynthetic-Encased Columns.” Geosynthetics International 18, no. 1 (February 2011): 12-20. doi:10.1680/gein.2011.18.1.12.

[26] Zhou, Yang, and Gangqiang Kong. "Deformation Analysis of Geosynthetic-Encased Stone Column-Supported Embankment Considering Radial Bulging." International Journal of Geomechanics 19, no. 6 (June 2019): 04019057. doi:10.1061/(asce)gm.1943-5622.0001426.

[27] Duan, Yuan-yu, Yi-ping Zhang, Dave Chan, and Ya-nan Yu. "Theoretical Elastoplastic Analysis for Foundations with Geosynthetic-Encased Columns.” Journal of Zhejiang University SCIENCE A 13, no. 7 (July 2012): 506-518. doi:10.1631/jzus.a1100334.

[28] Araujo, G.L.S., E.M. Palmeira, and R.P. Cunha. "Behaviour of Geosynthetic-Encased Granular Columns in Porous Collapsible Soil.” Geosynthetics International 16, no. 6 (December 2009): 433-451. doi:10.1680/gein.2009.16.6.433.

[29] Kaliakin, Victor N., Majid Khabbazian, and Christopher L. Meehan. "Modeling the Behavior of Geosynthetic Encased Columns: Influence of Granular Soil Constitutive Model.” International Journal of Geomechanics 12, no. 4 (August 2012): 357-369. doi:10.1061/(asce)gm.1943-5622.0000084.

[30] Keykhosropur, L., A. Soroush, and R. Imam. "3D Numerical Analyses of Geosynthetic Encased Stone Columns." Geotextiles and Geomembranes 35 (December 2012): 61-68. doi:10.1016/j.geotexmem.2012.07.005.

[31] Murugesan, S, and K Rajagopal. "Geosynthetic-Encased Stone Columns: Numerical Evaluation." Geotextiles and Geomembranes 24, no. 6 (December 2006): 349-358. doi:10.1016/j.geotexmem.2006.05.001.

[32] Yoo, C., and S.-B. Kim. "Numerical Modeling of Geosynthetic-Encased Stone Column-Reinforced Ground." Geosynthetics International 16, no. 3 (June 2009): 116-126. doi:10.1680/gein.2009.16.3.116.

[33] Akili, W., and J. K. Torrance. "The Development and Geotechnical Problems of Sabkha, with Preliminary Experiments on the Static Penetration Resistance of Cemented Sands.” Quarterly Journal of Engineering Geology and Hydrogeology 14, no. 1 (February 1981): 59-73. doi:10.1144/gsl.qjeg.1981.014.01.05.

[34] Abduljauwad, S.N., and O.S.B. Al-Amoudi. "Geotechnical Behaviour of Saline Sabkha Soils." Géotechnique 45, no. 3 (September 1995): 425-445. doi:10.1680/geot.1995.45.3.425.

[35] Zhang, Ling, and Minghua Zhao. "Deformation Analysis of Geotextile-Encased Stone Columns." International Journal of Geomechanics 15, no. 3 (June 2015): 04014053. doi:10.1061/(asce)gm.1943-5622.0000389.

[36] Benmebarek, Sadok, Fouad Berrabah, and Naïma Benmebarek. "Effect of Geosynthetic Reinforced Embankment on Locally Weak Zones by Numerical Approach." Computers and Geotechnics 65 (April 2015): 115-125. doi:10.1016/j.compgeo.2014.12.004.

[37] Khan, Iqbal H., and Syed I. Hasnain. "Engineering Properties of Sabkha Soils in the Benghazi Plain and Construction Problems.” Engineering Geology 17, no. 3 (October 1981): 175-183. doi:10.1016/0013-7952(81)90082-x.

[38] Lai, Fengwen, Fuquan Chen, and Dayong Li. "Bearing Capacity Characteristics and Failure Modes of Low GeosyntheticReinforced Embankments Overlying Voids.” International Journal of Geomechanics 18, no. 8 (August 2018): 04018085. doi:10.1061/(asce)gm.1943-5622.0001206.

[39] Alkhorshid, Nima Rostami, Gregório Luís Silva Araújo, and Ennio Marques Palmeira. "Behavior of Geosynthetic-Encased Stone Columns in Soft Clay: Numerical and Analytical Evaluations.” Soils and Rocks 41, no. 3 (December 24, 2018): 333343. doi: $10.28927 / \mathrm{sr} .413333$.

[40] Elsawy, M.B.D. "Behaviour of Soft Ground Improved by Conventional and Geogrid-Encased Stone Columns, Based on FEM Study.” Geosynthetics International 20, no. 4 (August 2013): 276-285. doi:10.1680/gein.13.00017.

[41] Yoo, Chungsik. "Settlement Behavior of Embankment on Geosynthetic-Encased Stone Column Installed Soft Ground - A Numerical Investigation." Geotextiles and Geomembranes 43, no. 6 (November 2015): 484-492. doi:10.1016/j.geotexmem.2015.07.014.

[42] Almeida, Marcio S. S., Iman Hosseinpour, Mario Riccio, and Dimiter Alexiew. "Behavior of Geotextile-Encased Granular Columns Supporting Test Embankment on Soft Deposit.” Journal of Geotechnical and Geoenvironmental Engineering 141, no. 3 (March 2015): 04014116. doi:10.1061/(asce)gt.1943-5606.0001256.

[43] Collin, J. G. "Column supported embankment design considerations." In Proceedings of the 52nd annual geotechnical engineering conference. Minnesota, (2004): 51-78. 